\title{
The Wolf Economy and Natural Resource Trap
}

\author{
D. Tuvshinjargal and P. Avralt-Od
}

\begin{abstract}
Mongolia is one of the richest countries in the world in terms of mineral endowments, and its medium and long-term outlook of the growth seem favorable. Even though mining sector development is likely to create opportunities for high economic growth in Mongolia, there have been several issues that need to be taken into consideration such as the impact of Dutch disease and the resource curse. According to the political risk index by the ICRG, the level of the Mongolian institutional quality is closer to the countries recognized as struggling with the curse of natural resources, which indicates that there is high potential for the rent seekers or corruption activities are likely to increase. Therefore, it is anticipated that the mining boom is having a negative impact on the Mongolian economy in line with resource curse theory. In other words, unless the government takes measures to improve governance and strengthen institutions in the country including implementing an effective anticorruption framework, the Mongolian economy is expected to be trapped in a resource curse, instead of being blessed with its new mineral wealth.
\end{abstract}

Index Terms-Mongolia, resources curse, institutions, wolf economy.

\section{INTRODUCTION}

Mongolia, which is rich in mineral resources, is a landlocked country between Russia and China. The country possesses substantial reserves of 80 different minerals including copper, gold, coking coal, iron ore, fluorspar, molybdenum. The largest income comes from copper, coal and gold. It also has tremendous potential for more discoveries since many parts are still not explored [1]. Mongolia's abundant natural resources have been encouraging and attracting many foreign investors to Mongolia. Two of the main deposits that have been discussed extensively are Oyu Tolgoi and Tavan Tolgoi deposits. In October 2009, the Government of Mongolia (GoM) signed an agreement on the establishment and operation of the $O y u$ Tolgoi deposit with an international mining company, owning $34 \%$ of the mine. Oyu Tolgoi deposit is estimated to become the 3rd largest copper mine in the world including 24 million tons of copper, 874 tons of gold and 5589 tons of silver reserve discovered during the mine life of 59 years. Besides Oyu Tolgoi, there are other plans for developing mines of mineral resources, which are already discovered. Tavan Tolgoi coal mine is the second largest mining investment in Mongolia with reserve of 6.5 billion tons of high quality coking coal, which is equivalent to 8 months of world consumption of coking coal.

\footnotetext{
Manuscript received March 10, 2014; revised May 13, 2014

The authors are with the Institute of Finance and Economics, Ulaanbaatar, $13381 \quad$ Mongolia (e-mail: tuvshinjargal.d@ife.edu.mn,
} avraltod@email.arizona.edu).
Looking the economic performance, the current economic liberalization initiated 20 years ago has been defined as a Wolf economy according to CNN report, which infers the possibility that the country may follow rapid economic development experienced in economies of the Asian Tigers [2]. The economy has been growing rapidly, about $8.5 \%$ on an annual basis over the last 8 years. Even though the economy was relatively small with GDP of US\$ 1.3 billion in 2000 , it has increased quickly during the decade and reached US\$ 14.4 billion by the end of 2011. However, being continuously dependent on the mining sector, the Mongolian economy has been highly affected by the worldwide commodity market fluctuations. Economic growth which was $8.9 \%$ in 2008 , slowed to $-1.3 \%$ in 2009 due to the global economic downturn. The sector that suffered most during the crisis was mineral sector as a result of the copper price decline starting from 2007 where the scope of the downturn in mineral GDP growth was very low and its contribution to GDP has become almost invisible from 2007 to 2008. Growth reached $6.4 \%$ in 2010 and $17.3 \%$ in 2011, which is the highest annual growth ever accounted for the last 20 years [3].

This also indicates that Mongolia faces critical policy challenges. The Mongolian medium and long-term growth outlook seem favorable because its large mineral reserves are likely to provide the country potential to grow rapidly and could raise living standards significantly. However, international experience shows that mineral reserves do not guarantee prosperity and that rents from their exploitation need to be invested wisely to ensure sustainable growth in the long-run. It is obvious that resource-rich countries have faced problems ranging from corruption to internal conflict. Therefore, it is highly recommended that the GoM should learn from other country experiences that have managed their mineral wealth successfully. In other words, there are concerns about the economy's capacity to cope with the requirements of these mining projects. It is highlighted that there is a risk of Dutch disease or resource curse, indicating whether the Mongolian economy is blessed or cursed with the natural resources as some economists have warned due to the continued expansion of the mining sector.

The purpose of this paper is to analyze the impact of mining boom on the Mongolian economy and to address the following questions: (i) what are the implications for Mongolia as the economic dependency on the mining sector continues to increase dramatically?; and (ii) Can prominent developmental or economic theories offer any insight for the Mongolian current situation or more specifically is some version of the resource curse theory applicable to Mongolia? The rest of this paper is organized as follows. First, the paper will evaluate a structural change of the Mongolian economy emphasizing on the impact of the mining sector by the Dutch 
disease effect. Following that, it will then be examined whether two channels identify rent seeking and institutional barrier correspond with Mongolia's development given Mongolian economic and political situation between 2005 and 2011. Finally, the key findings will be summarized with some policy implications to address whether research questions have been answered sufficiently or not.

\section{LITERATURE REVIEW}

In order to explore thoroughly the implications of the Mongolian mining boom, it is necessary to consider the existing research on resource-led development. Therefore, this section provides an overview of the relevant research literature focusing on recent debates surrounding the resource curse thesis to identify relevant theoretical insights. In order to assess the implications to the economy and to address how applicable the resource curse is, it is particularly important to study of the existing research on resource-led development by emphasizing more on country experiences.

Known as the paradox of plenty, the natural resource curse hypothesis is based on the observation that refers to a paradoxical developmental phenomenon where in resource-rich economies grow slower, on average, than resource-poor economies [4]-[9].

\section{A. Underlying Mechanisms of the Resource Curse}

In the beginning of 2000s, more critical and new versions of the theory and research trends have emerged alongside significant challenges and proposals for alternative frameworks to identify the underlying mechanism of the resource curse. One possible explanation for the natural resource curse is that resource wealth tends to create conflict over existing resources, which in turn leads to poor institutional quality and lower economic growth. Reference [10] argue that the presence of common-pool problems or uncertainty related to property rights over the resource income leads to inefficiencies in the use of existing resources, which can generate lower growth. Reference [11] call this the institutional impact of natural resources, and find empirical evidence that some natural resources (in particular, oil and minerals) exert a robust negative and nonlinear impact on growth via their harmful impact on institutional quality.

A second explanation for the natural resource curse is that resource rents tend to be volatile. This volatility arises in part from the fact that natural resources typically have a low price elasticity of supply. Volatility, in turn, has been shown to be negatively correlated with growth [12] and investment [13], including investment in education [14].

A third explanation of the resource curse is the hypothesis commonly known as Dutch disease. Going back to [15], [16] the Dutch disease hypothesis is briefly summarized as the notion that an exogenous increase in resource prices or in resource output results in real exchange rate appreciation and a decline in the manufacturing sector. Under certain conditions, which we will describe below, this can lead to lower growth in the long-run. The predictions of the Dutch disease model following [16], distinguishes between a resource movement effect and a spending effect. While the resource movement effect (the tendency of a booming resource sector to draw capital and labor away from a country's manufacturing and agricultural sectors, raising their production costs) is unlikely to be important in developing countries, the spending effect (the appreciation of a state's real exchange rate caused by the sharp rise in exports) is likely to be important. The resource movement effect only occurs if factors are sufficiently mobile between the mining and non-mining sectors, which is unlikely in Mongolia given that the mining sector employs relatively few workers and labor mobility is low in general. However, the spending effect happens regardless of whether the mining sector employs any labor at all. The spending effect occurs simply because higher commodity prices generate higher wages and/or profits in the mining sector, thus raising aggregate demand in the economy. Together these factors can lead to a decline in the export of agricultural and manufactured goods and can inflate the cost of other goods and services which cannot be imported.

Recent research studies highlighted a rather different view about resource curse. According to some scholars including [17]-[19], whether a country would fall into a resource curse theory will highly dependent on its government policies and institutional capacity. This new theoretical interpretation was initiated from a neoliberal theoretical framework grounded in neoclassical economics to a New Institutional Economics (NIE) framework. In accordance with NIE, good governance and state intervention in market are significant to enable countries to perform efficiently and to prevent potential excesses [20], [21].

\section{B. Gap in the Literature Review}

The above literature review indicates that a number of studies have mainly examined the Dutch disease effects on economies that have abundant natural resources. However, hardly any research has been carried out for Mongolian economy yet. An exception is [22] study that evaluates the impact of the Oyu Tolgoi project on the Mongolian economy using a dynamic CGE model. The results suggest that the development of the mineral sector will have significant and long-term positive effects on the Mongolian economy and clearly show that responsible fiscal policy can help to reduce the risk of Dutch disease in the Mongolian economy. To our best knowledge, assessments of the applicability of the resource curse hypothesis to the Mongolian economy emphasizing institutional and political implications of the mining boom in the economy have been neglected. Given the shortcomings in the existing literature, this paper examines whether Mongolia's newly exploited mineral wealth is in the process of being transformed from a blessing for development into a curse. Based on both resource cursing and blessing country experiences, it can be suggested that Mongolia, as a developing country with a growing reliance on primary commodity exports, should carefully examine country cases in detail. Although there have been a number of different versions of models and various critiques of the resource curse, theoretical insights and recent research suggest some crucial aspects that Mongolia should take into consideration. 


\section{UNDERLYING MECHANISMS OF THE RESOURCE CURSE IN MONGOLIA}

The Hypothesis of the resource curse in literature review suggest that the resource rich countries in fact, with a point ore resource such as oil, diamond and minerals face a political and economic trap. And indeed, the most of these countries have fallen on the trap in the sense that a higher commodity price only has positive short-term effect on an economy, but adverse long-term effects, consequently, they are collapsed rather a blessing of resource [23]. In addition, the positive short-term effects of the higher commodity prices have not been transformed to the negative long-term effects by an individual economic channel. In other words, there have been several proposed channels such as governance, conflict, rent-seeking so on, despite of the Dutch disease effect.

For Mongolia, even though the abundant natural resources have been recently started to shift toward the international market, since 2005, there has been a structural change in the economy, so that the mining sector has produced the most of total GDP and the economic growth is determined by the prices of mineral products in the international market: in 2010 it contributes the most with a $23.8 \%$ share of the total GDP followed by agriculture with $14.3 \%$.

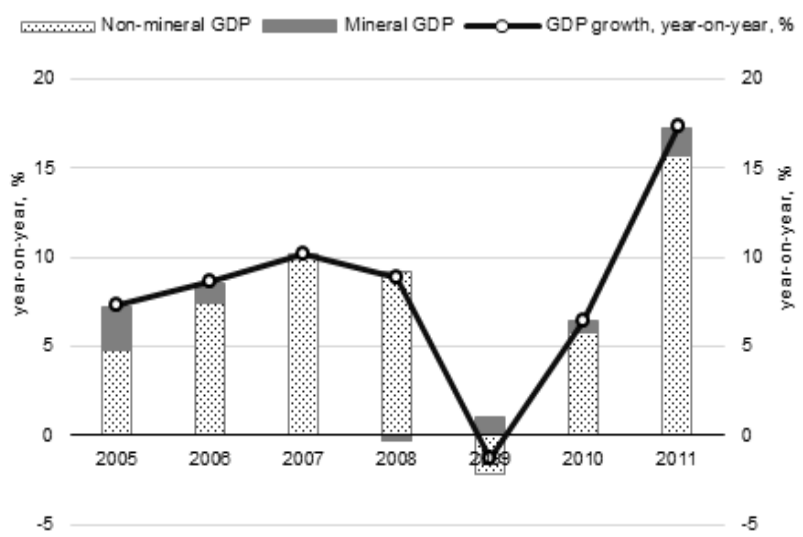

Fig. 1. Mineral, non-mineral and overall GDP growth, (\%).

As expected and in Fig. 1, Mongolia as same as other the resource rich countries which suffered from the resource curse may have fallen on the political and economic trap. Because of, as shown in Fig. 2, the GoM has collected sizable windfall revenue from the mining sector in the sense that the mineral rents as the percent of non-mining GDP was $20.5 \%$ in base period or 2005 increased rapidly to $32.5 \%$ in the 2006-2007 and again reached to $44.6 \%$ in the $2010-2011^{1}$. But the fluctuation of the economic growth during the 2005-2011 shows that recent mining booms are seemed to be only positive the short-term effects on the Mongolian economy or it has been remained to follow the mining cycle

\footnotetext{
${ }^{1}$ In particular, in May 2006, the Parliament of Mongolia (PoM) was appointed newly the 68 percent windfall profit tax law on copper and gold production when their price exceed preset levels as well as the law implementing period between June 2006 and December 2010 the GoM has collected MNT 1529.6 billion (70\% as non-mining GDP in 2005) from the 68 percent Windfall Profits tax.
}

(Fig. 1).

Despite this fact, it was experiencing a similar pattern found on other resource rich countries as the windfall revenues build up from first and second mining boom is distributed mainly on the economy due to public investment. More specifically, during the first mining boom of the 2006-2007 either the wage in public sector increased annually by $28 \%$ in 2006 and $40 \%$ in 2007 or the budget captical cost skyrocketed per year in both 2007 and 2008 by $95.7 \%$ and $70.5 \%$ respectively as well as there have been a similar tendency of the absorbing before for second mining boom of the 2010-2011. In addition to this, in november 2009 the PoM was appointed a law of the Human Development funds in order to distribure of benefits of the mining boom more widely, following completion of the Oyu Tolgoi negotiations ${ }^{2}$. Thus, according to this act, the some extra revenue of windfall rents were transferred to every citizens by cash handouts and total amount of the transfer were MNT 277.1 billion in 2010 and MNT 733.1 in 2011 billion respectively ${ }^{3}$.

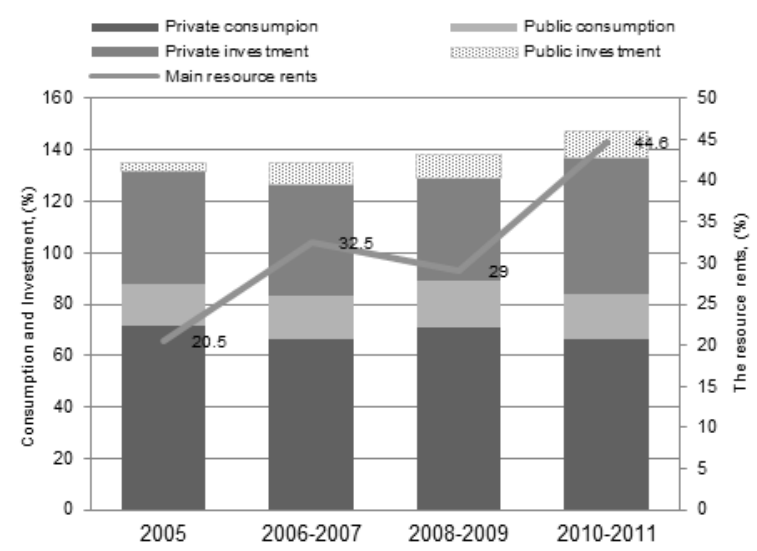

Fig. 2. Resource rents and an overall absorbing of the windfall, Mongolia (the share of non-mining GDP, \%).

Notably, here, as of the 1970s the oil-producer countries with the large amount of windfall revenue were distributed substantially on the public investment such as infrastructure and heavy industry. However, in the most of these countries, the uses of windfall revenue were not corresponded with these development policies or have trapped on the resource curse. Therefore, it demonstrates that the GoM what is choosing a way which the most of resource rents is absorbed on domestic economy due to public investment faces to the challenge that the uses of windfall revenues would suffer the Mongolian economy in the long-run. In other words, the

\footnotetext{
${ }^{2}$ By law, the Human Development Fund is financed from mining dividends pertaining to the state an unspecified part of royalty payments to the budget. The funds can be used for cash handouts to all citizens, as well as for payments linked to pensions, health care, education and housing.

${ }^{3}$ The initial contribution to the fund came from a negotiated prepayment of Oyu Tolgoi royalty. In February 2010 every citizen received a cash handout of MNT 70,000 (equivalent to about US\$ 50), followed by another MNT 50,000 in that year. In 2011 monthly cash handouts were sustained at MNT 21,000 (around US\$ 15) and approximately a quarter of this amount was additionally distributed as tuition fee support, leading to projected annual spending of around US\$ 580 million (almost 10 percent of 2010 GDP).
} 
channels proposed in the literature review of the resource curse have occurred whether individually or coexistent in Mongolia.

In order to discuss the Mongolian case in detail and to address that question in a coherent manner, first, the traditional economic channel in the resource curse theory, namely the Dutch Disease effect will be evaluated to whether the Mongolian economy is blessed or cursed with the natural resource and then will be moved to other channels related to less institutional constraints.

\section{A. Traditional Economic Channel: The Dutch Disease Effect}

As the absorbing of the windfall revenue exceeds the capacity of an economy, real exchange rate will tend to appreciate pass-through the relative price of nontrade sectors rises. And when a government does not implement protective policies for non-mining industries, this tendency will be associated with a production shift toward the nontrade sectors such as service and construction. In fact, this is called the Dutch Disease effect which in long run, a country with abundant natural resources would fall on the resource curse due to an inappropriate structural change in the economy. In initial studies, the resource curse have been explained by this channel or as the higher price of the primary products on a country's exports can influence negatively on its growth in per capita income in the long-run [4]-[6].

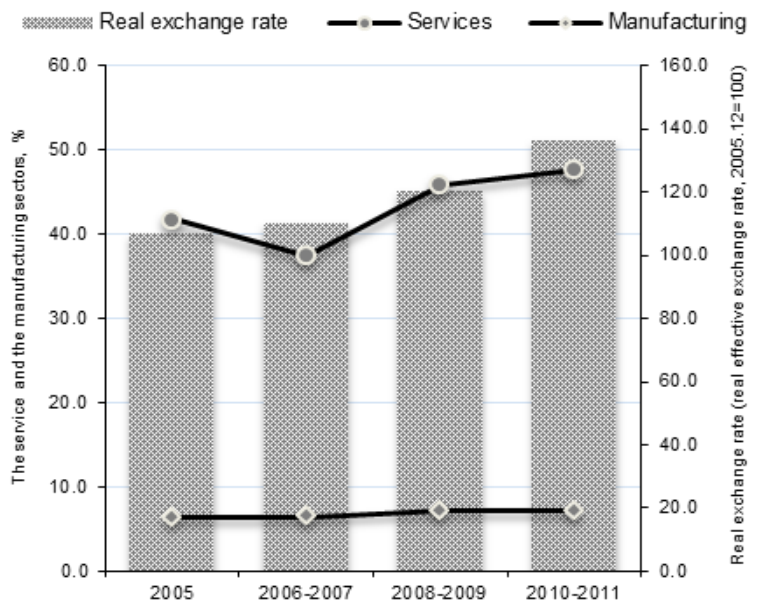

Fig. 3. Manufacturing and services (\%/GDP) and real exchange rate.

As shown in Fig. 3, a real exchange rate appreciation has been starting continuously since 2005 in Mongolia. According to the Dutch disease hypothesis, the response to exchange rate appreciation is expected that non-tradable sector such as service and construction rises, but both manufacturing and agriculture sector decline. The service sector as the percent of GDP increased following of Dutch disease predict during the second mining boom in the 2010-2011 even though it has declined during the first mining boom in the 2006-2007 (Fig. 3).

In addition, a dominant agriculture sector has decreased to $15.8 \%$ as the percent of non-mining GDP in 2011 which was just below $30.0 \%$ in 2005 according to the prediction of the Dutch Disease. And indeed, the GoM implemented the program of crops including cereals and wheat, namely "Atrin
3 ayan" from 2008 in order to plant the quantities of crops which meet completely the domestic consupmtion and so resulted in a higher level production 1.9 times as large as in 2008 and 3.5 times in 2009 from 2007. Even though this program could contributes an increase in the agriculture sector, there have not been the investment oriented the livestock sector which is traditionally the largest sector on agriculture (84.7\% as the percent of gross agricultural output in 2005). Because of, it reveals as a situation that harsh winter condition (a dzud) in 2010 reduced a quarter of the total livestock, so that resulted in agricultural output being reduced by $17 \%$ in 2010 [3]. Notably, here, there have been remarkably the Dutch Disease effect in Nigeria what it transmitted through the dropping in their traditional agriculture sector or destroy in the sense that as of 1972, the agriculture was dominant sector in the Nigerian economy because of $39.2 \%$ as the non-mining GDP. However, a substantial part of oil windfall revenue from the oil boom was distributed on the nontrade sector including road construction and the spread of primary education, urban biased infrastructure resulted in rapid real exchange rate appreciation so the agricultural output reduced then Nigeria became a net importer of agricultural product in 1975! [8].

Thus, in Mongolia, there have been a tendency for the economy shift toward the nontrade sector because the ongoing appreciation of real exchange rate in the sense that the economy with a large agriculture sector has relied on the mining sector or move to the mining economy. But in Mongolian case, other channels of the resource curse should to be explained the situation of the Mongolian economy over the period. In other words, according to the literature reviews, the wage increasing in public sector, the substantial part of windfall absorbing in the economy through public investment, cash handouts for remain on the former office, and the post-election riot in 2008 will be explained by the alternative channels of the resource curse.

\section{B. Other Channels Based on Weak Institutional Barrier to Rent-Seeking}

Recently, or since the 2000s, there have been the increasing explanations for the resource abundant is most likely to be the curse depends not only the Dutch disease effect, but also a resource feature, rent-seeking, social conflict, inequality of income, the fluctuation of price in mineral products, and political institutions, so developing a theory and an empirical supporting on the resource curse. In particular, in the framework of New Institutional Economics (NIE), some leading scholars including [7], [18] argue that the resource rents lead to rent-seeking and inefficient redistribution in the countries with weak governance but not in the countries with strong governance. This suggests that the resource curse occurs conditional on weak governance. But the hypothesis are based on institutional constraints demonstrate that a large amount of windfall revenue are not transmitted by single channel like economic channel, to the resource curse. The scholars have defined different channels are based on weak institutional constraints by the underlying transmissions are correspond any attribute of the institutional environment on each model for the resource curse. Specifically, in the framework of NIE, the studies of the 
resource curse are identified that the rent-seeking behaviors that powerful groups extract resource rents through government's instruments or diverting entrepreneurial talent away from industrialization with positive externality and toward rent-seeking. In the remaining of this section, it is explored these different ways to the expected large amount of the windfall revenue are likely to be the curse, then tests whether occurs in Mongolia due to weak institutional barrier to rent-seeking.

\section{1) The "voracity" model, rent-seeking}

The "Voracity" model what is a polar case of rent-seeking predicts that government's coercive power such as some taxes, theft, forced participation, and nationalization or expropriation is used to solely to transfer wealth from the private sector to powerful interests. According the model's assumptions, the private sector's capital stock is likely common pool, and political powerful groups independently transfers private sector wealth to themselves. But the voracity only operates in the absence of institutional barriers to rent-seeking [24]. This provides an explanation on Norway versus Nigeria why economic performances following the oil boom of the 1970s were so different and directs to allow for different resource boom effects in different institutional contexts [25].

In the study of testing for the Voracity model, [25] investigate the response of transfers and economic growth rates to oil price shocks, and compare economic performance in the 1970-1980s in three oil rich country: Nigeria, Venezuela, and Mexico. As their finding, all three countries had low institutional quality and government transfers more than doubled during the period. However, in the same period, the growth of GDP growth rates in all three countries were well below predicted value and were actually negative in Nigeria and Venezuela. There have been a tendency in oil rich countries that in the 1970s or the same period of first oil boom, all of the countries saw expensive and growing public involvement in the oil industry resulted in the governments nationalized both domestic and foreign oil companies, then were established the state oil company or the governments became oil producers.

In Mongolia, it has the similar tendency in the oil rich economies because in 2005 the economic significance of the mining sector was recognized, so the extension of public involvement over the sector by both direct and indirect way have started from 2006 in the sense that an increase in mineral products had led the state to stressed increased national control over the mining sector by the government acting either changing tax over mineral product or an increase in partnership with concerns. In fact, in May 2006, the PoM was appointed the act of the 68 percent Windfall Profits tax for some mineral products as well as in July 2006, an amendment was passed to the 1997 Minerals law that was established a classification of mineral deposit of strategic importance, in accordance with the 2006 amendments on the mineral law, which gives the government the option to acquire interests in mineral deposits that are considered "strategic" because they could have an impact on Mongolian national security and economic and social development [26] ${ }^{4}$. This resulted in the PoM as same as the oil-rich countries became a producer in mining sector. Then in February 2007, the PoM has announced 15 mineral deposits of strategic importance including the Oyu-Tolgoi deposit and Tavan Tolgoi deposit use in near-term as well as the next 30 mineral deposit in the future. In addition to this, before the GoM signed an agreement on the establishment and operation of the Oyu-Tolgoi deposit with an international company, in January 2009 the PoM had made another amendment to the 2006 minerals law for clearly establish state ownership on mineral deposit of strategic importance strategic ${ }^{5}$. In accordance this change, the PoM claims substantial ownership stakes in new mining projects. Moreover, since 2010 price of cocking coal have increased in the international market, the cocking coal have emerged in export value of mineral products as well as in November 2010 was made next amendment on the minerals law to establish the progressive of royalty tax depending on production level even the 2006 amendment to the mineral law doubled the royalty rate on minerals 2.5 percent to 5 percent.

TABLE I: THE INSTITUTIONAL QUALITY

\begin{tabular}{lcc}
\hline \hline \multicolumn{1}{c}{ Country } & $\begin{array}{c}\text { Estimated } \\
\text { year }\end{array}$ & $\begin{array}{c}\text { Composite risk Index } \\
(0-100)\end{array}$ \\
\hline Mongolia & 2005 & 66.06 \\
Botswana & 1985 & 68.08 \\
Nigeria & 1985 & 44.17 \\
Chile & 1990 & 66.50 \\
Venezuela & 1985 & 64.00 \\
Norway & 1985 & 89.71 \\
Mexico & 1985 & 68.96 \\
\hline \hline
\end{tabular}

Note: The institutional quality is measured by the composity risk index, which includes three assessment index namely economic, political, and financial risk. Each assessment index scores from 0 to 100 point, which higher value indicates declining risk level. In order to comparing of institutioal quality on whether a country suffered from the resource curse or a country resource blessing at the time, which it was started to windfall the resource, we cover as of 2005 in Mongolia.

Thus, Mongolia is expected to similar to discussed results of both Nigeria and Venezuela that there were in the absent institutional barrier to rent-seeking so resulted in private asset transferred to powerful group through government transfer and the extending public control in the oil industry. Therefore, to study the increasing public involvement in mining sector relate to whether weak institutional barrier to rent-seeking,

\footnotetext{
${ }^{4}$ Mineral deposit of strategic importance in Article 4.12 of this law means a deposit [with size] that may have a potential impact on national security, economic and social development of the country at the national and regional levels or that is producing or has a potential of producing more than five (5) percent of total Gross Domestic Product in a given year.

${ }^{5}$ In article 5.4 of the 2006 minerals law, the state may participate up to $50 \%$ jointly with a private legal person in the exploitation of a minerals deposit of strategic importance where State funded exploration was used to determine proven reserves. The percentage of the State share shall be determined by an agreement on exploitation of the deposit considering the amount of investment made by the State. Also, in article 5.5, The State may own up to $34 \%$ of the shares of the investment made by a license holder in a mineral deposit of strategic importance where proven reserves were determined through funding sources other than the State budget. The percentage of the State share shall be determined by an agreement on exploitation of the deposit considering the amount of investment made by the State.
} 
we compare an institutional quality in Mongolia with both Chile, Botswana and Norway which are a blessing of natural resource, and Nigeria, Venezuela and Mexico which are trapped on the resource curse.

In this study, the institutional quality in Mongolia is evaluated using the composite risk index is compiled by [27]. This index has three components which are economic risk, political index, and financial index. Table I draws that the institutional quality in Mongolia and selecting countries by the period that these countries started to extract the mineral resource.

According to the composite index, as of 2005, the institutional quality in Mongolia was close to Chile, Botswana, Mexico, and Venezuela, whereas, was weakly than Norway, higher than Nigeria. But in an empirical study, the scholars actually use the political risk index for assessing institutional quality, which weighs by 50 percent on the composite index. Table II is depicted the institutional quality in Mongolia by this index with Norway, Botswana and Nigeria. In addition to the result, as shown Table II, as of 2011, the institutional quality in Mongolia deteriorated, in particular, in the field of control of corruption was the lowest level as well as have not increased comparing to the base period. Moreover, the regulation quality which indicates an institutional environment of contract enforcement and investment expropriation declined during the period.

\begin{tabular}{|c|c|c|c|c|c|}
\hline \multirow[t]{2}{*}{ Items } & \multicolumn{2}{|c|}{ Mongolia } & \multirow{2}{*}{$\begin{array}{c}\text { Botswana } \\
2011\end{array}$} & \multirow{2}{*}{$\begin{array}{c}\text { Norway } \\
2011\end{array}$} & \multirow{2}{*}{$\begin{array}{c}\text { Nigeria } \\
2011\end{array}$} \\
\hline & 2005 & 2011 & & & \\
\hline VA & 0.75 & 0.75 & 0.71 & 1.00 & 0.46 \\
\hline PV & 0.81 & 0.80 & 0.76 & 0.77 & 0.56 \\
\hline GE & 0.50 & 0.50 & 0.50 & 1.00 & 0.25 \\
\hline RQ & 0.64 & 0.50 & 0.86 & 0.95 & 0.50 \\
\hline RL & 0.67 & 0.67 & 0.58 & 1.00 & 0.33 \\
\hline $\mathrm{CC}$ & 0.33 & 0.33 & 0.58 & 0.83 & 0.25 \\
\hline
\end{tabular}

Note: VA-Voice and Accountability, PV-Political Stability and Absence of Violence, GE-Government Effectiveness, RQ- Regulatory Quality, RL-Rule of Law, CC-Corruption. Each component takes from 0 to 1 point, which higher point indicates less risk.

In comparing with Norway and Botswana by this index, Mongolia had weak institutions, especially control corruption, and support investment and contract enforcement. Reference [7]'s study is evidenced that the voracity effect to operate likely depends not only institutional quality or powerful rent-seeking group. Reference [28] found an empirical result which is support to this prediction on a country with high ethnic polarization. In Mongolian case, even though it has many ethnic groups, most of people are distributed on one group namely khalkh by about 80 percent, so we expect that ethnic polarization could not be reason of rent-seeking [3]. Instead, political party group might be a powerful rent-seeking group because only two big political party, namely the Democratic Party and the Mongolian people's party have been controlling the state despite of the fact that there are many political parties have built and registered since last 20 years. From the result that the increase both in corruption and the involvement of the GoM in the economy (Table II and Fig. 2) we expect that there have been a competition on between two big parties to getting for a large amount of resource rents during the mining booms. Thus, we predict that the voracity effect is applicable on the situation in the Mongolian economy in the selection period, so that powerful rent-seeking groups pass through political party have competed to the large amount rents in the mining sector in order to transfer to themselves.

\section{2) Misallocation of entrepreneurial talent, rent seeking}

This channel of the resource curse has a specific transmission mechanism that the resource windfall becomes the curse by diverting entrepreneurial talent away from wealth creating industrialization and toward rent-seeking, is developed by [29]. Because industrial sector facilitates adoption modern production method elsewhere in the economy, a resource rent boom makes rent-seeking more attractive and causes some producing entrepreneurs to abandon industrial production, with the demand externality, result in loss economy-wide income. However, according this model, high institutional quality will prevent the resource curse from occurring because rent-seeking never becomes sufficiently lucrative to attract entrepreneurs away from modern industrial production. Reference [29] describes these institutions as producer friendly institutions, which rich resources attract entrepreneurs into production, implying higher growth. If institutional quality is below a critical level, however, the same resource rents will divert entrepreneurial talent and the resource curse will ensue. These institutions are defined as grabber friendly there are gains from specialization in unproductive influence activities or rent-seeking.

\begin{tabular}{lc} 
TABLE III: THE DISTRIBUTION OF GROSS INVESTMENT IN 2011 \\
\hline \hline Sectors & $\begin{array}{c}\text { Percentage of the } \\
\text { Investment }\end{array}$ \\
\hline Mining & 62 \\
Construction & 12 \\
Wholesale and retail trade & 4 \\
Financial and insurance services & 3 \\
Transportation and communication & 3 \\
Other & 16 \\
\hline \hline
\end{tabular}

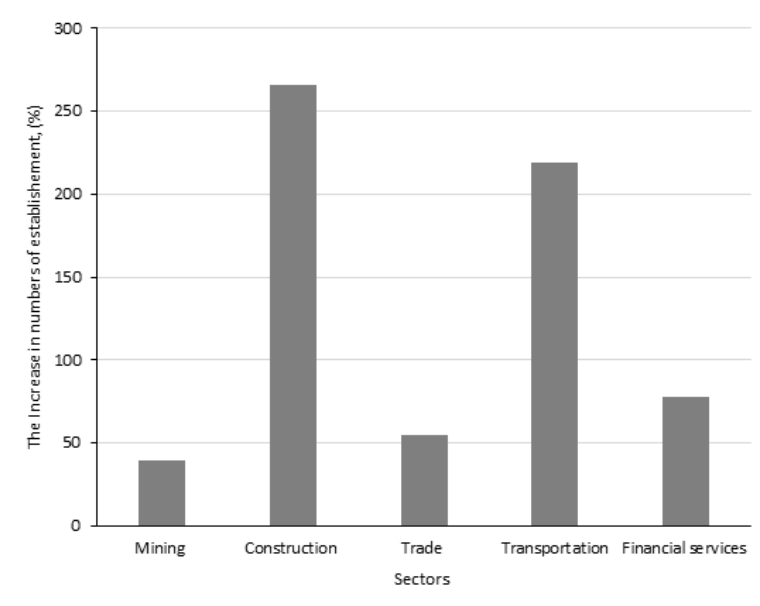

Fig. 4. An increase in the numbers of establishement in Mongolia between 2005 and 2011.

When Reference [18] test the result of [4]'s influential works on the resource curse by this channel, they also use the composite risk index from [27] for institutional quality. 
According to this index, there have been weak institutional constraints in Mongolia, so it could not constraint to more entrepreneurs to switch to rent seeking in the mining sector (Table I and Table II). As shown in Table III, the most of total investment was centralized to mining sector by $62 \%$ in 2011 as well as the next top sectors attract the investment were transportation, finance, wholesale and retail trade which these support the mining sector or coexistent with each other.

Moreover, the number of establishment in the sectors have increased rapidly between 2005 and 2011, in particular, the enterprises in transportation have rose over 2 times as large as than 2005 (Fig. 4).

These results show clearly that because of weak institutional barrier to rent seeking, a sizable entrepreneurial talent shift toward rent-seeking for outstanding rents through import, service, transport, other related sectors with absorbing of windfall revenue such as construction, real state.

Recently, Reference [30] found to the similar results that the mining share in GDP was around $20 \%$ in 2011 , but the rest of the Mongolian economy more dependent on the mining sector than ever before ${ }^{6}$. It clearly shows that two commercial banks "Zoos" and "Anod" turned in receiverships during the 2008-2009 global crises as their exposure to the mining sector was intolerably high.

In addition, in 2011, the IMF suggested on the report of Mongolia that credit risk remains the principal vulnerability for banks because the fragility of the banking sector is heightened by large single borrower and sectorial loan concentrations in the sense that cross-ownership linkages among banks and between banks and industrial companies resulted in significant loans made to borrowers that are related parties of banks [31] $]^{7}$.

Thus, we also predict that significant amount of entrepreneurial talent have switched to the mining sector or other sectors which complements mining sector such us transport, trade, finance and service. In order words, there is in the absent institutional barrier will prevent to attract entrepreneurs away from industrial production for rent-seeking as well as support economic diversification. So the situation in the Mongolian economy during boom-bust period is expected to correspond in part with this specific channel of the curse.

\section{CONCLUSION}

Mongolia is a typical developing country, which depends heavily on resource-based exports including copper, coal and gold. It has rich, confirmed mineral resources and a great potential for more discoveries as many parts of the country are still unexplored. It has been highlighted in many studies

\footnotetext{
${ }^{6} \mathrm{He}$ obtains the upward trending in the contemporaneous correlation between the real growth of the overall economy and copper price changes at the London Metals Exchange using data between 1983 and 2011.

Mongolian banks have large sectorial concentration and are vulnerable to sector-specific shocks that could arise particularly from the construction, mining, and trade sectors. Large corporate clients borrow across the industry and a single corporate default could potentially destabilize a number of banks as evidenced by the default of a gold mining company in 2008, which undermined the viability of several banks
}

that the Mongolian economy will be expected to rapidly grow in forthcoming years due to capital inflow and foreign direct investments driven by upcoming large-scale mining projects. Even though the mining sector development is likely to create opportunities for high economic growth in Mongolia, there have been several issues that need to be taken into consideration.

The result what even though public investment rose rapidly, it could not contribute on sustained economic growth or the economy have been remained to following the mining cycle. Thus, it shows that when the institutions support market economy have not been established well, Mongolia have increased rapidly mining sector so resulted in the increasing rent-seeking for additional rents as well as an institutional development response slowly to the mining booms. This is consistent with prediction of [32] that a country rich in resource endowment sometimes slows response to the reform which increases loss of outputs and the risk of policy corruption.

Finally, in the absent of good institutional supporting, it is seems to be not simply to develop non-mining industries and they compete with mining sector in the economy for non-mineral productive resources, so lead to the challenge is to contain the impact of natural resource production on macroeconomic volatility and to ensure that mining development does not crowd out development in other sectors of the economy in the near time.

\section{REFERENCES}

[1] C. Khashchuluun, "Current situation of Mongolia's economic development and its future trend. Development policies of Mongolia: Incorporating mining as a growth engine," presented at the Mongolia-Australia Forum, Ulaanbaatar, Mongolia, 2011.

[2] CNN. (May 20, 2011). Mining fuils Mongolia's wolf economy. [Online]. Available: http://www.cnn.com/2011/WORLD/asiapcf/05/19/mongolia.mining.e conomy/index.html

[3] Statistical Year Book, National Statistical Office of Mongolia, Ulaanbaatar, Mongolia, 2011.

[4] J. Sachs and A. Warner, "Natural resource abundance and economic growth," NBER Working Papers, no. 5398, Dec. 1995.

[5] "Sources of slow growth in African economics," Journal of African Economics, vol. 6, no. 3, pp. 335-376, 1997.

[6] "The Curse of Natural Resources," European Economic Review, vol 45, no. 4-6, pp. 827-838, 2001.

[7] P. R. Lane and A. Tornell, "Power, Growth, and the voracity effect," Journal of Economic Growth, vol. 1, no. 2, pp. 213-241, June 1996.

[8] A. Gelb, Oil Windfalls: Blessing or Curse? Oxford University Press, 1988.

[9] T. Gylfason, T. Herbertsson, and G. Zeoga, "A mixed blessing: Natural resources and economic growth," Macroeconomic Dynamics, vol. 3, pp. 204-225, 1999.

[10] R. Hausmann and R. Rigobon, "An alternative interpretation for the resource curse: Theory and policy implications," NBER Working Papers, no. 9424, Jan. 2003.

[11] X. S. Martin and A. Subramanian, "Addressing the natural resource curse: An illustration from Nigeria," Economics Working Papers, no. $685,2003$.

[12] G. Ramey and V. A. Ramey, "Cross-Country evidence on the link between volatility and growth," NBER Working Papers, no. 4959, Dec. 1994.

[13] J. Aizenman and N. Marion, "Volatility and investment: Interpreting evidence from developing countries," Economica, vol. 66, no. 262, pp. 157-179, May 1999.

[14] K. Flug, A. Spilimbergo, and E. Wachtenheim, "Investment in education: Do economic volatility and credit constraints matter?" Journal of Development Economics, vol. 55, pp. 465-484, Nov. 1998. 
[15] W. M. Corden and P. J. Neary, "Booming sector and De-Industrialisation in a small open economy," Economic Journal, vol. 92, no. 368, pp. 825-848, Dec. 1982.

[16] W. M. Corden, "Booming sector and Dutch disease economics: Survey and consolidation," Oxford Economic Papers, vol. 36, no. 3, pp. 359-380, Nov. 1984.

[17] A. D. Boschini, M. J. Lindquist, and J. Roine, "Learning to lose a leg: Casualties of Ph.D. economics training in Stockholm," Econ Journal Watch, vol. 1, no. 2, pp. 369-379, Aug. 2004.

[18] H. Mehlum, K. Moene, and R. Torvik, "Institutions and the resource curse," The Economic Journal, vol. 116, no. 508, pp. 1-20, 2006.

[19] I. Atsushi, "Escaping from the resource curse: Evidence from Botswana and the rest of the world," IMF Staff Papers, pp. 663-699, 2007.

[20] D. C. North, "Economic performance through time," American Economic Review, Dec. 1994.

[21] J. E. Stiglitz, "More instruments and broader goals: Moving toward the post-the Washington Consensus," Revista de Economia Politica, vol. 19, no. 1, pp. 94-120, 1999.

[22] B. Fisher et al., The Development of the Oyu Tolgoi Copper Mine: An Assessment of the Macroeconomics Consequences for Mongolia. Ulaanbaatar, School of Economic Studies, National University of Mongolia, BAEconomics Pty Ltd, 2010.

[23] P. Collier and B. Goderis, "Commodity prices, growth, and the natural resource curse: Reconciling a conundrum," CSAE Working Papers, no. 15, Aug. 2007.

[24] R. T. Deacon, The Political Economy of the Natural Resource Curse: A Survey of Theory and Evidence, now Publishers Incorparated, 2011.

[25] A. Tornell and P. R. Lane, "Voracity and growth," NBER Working Papers, no. 6498, 1998.

[26] Law of Mongolia on Windfall Tax, The Parliament of Mongolia, 2006.

[27] International Country Risk Guide, The Political Risks Service Group, 2012.

[28] R. Arezki and M. Bruckner, "Commodity windfalls, polarization, and net foreign assets: Panel data evidence on the voracity effect," IMF Working Paper, no. 10-209, Sep. 2010.

[29] R. Torvick, "Natural resources, rent-seeking and welfare," Journal of Development Economics, vol. 67, no. 2, pp. 455-470, 2002.
[30] B. Erdenebat, "Macroeconomic risks of Mongolia and ways to mitigate them," ERI Dscussion Paper Series, vol. 2, pp. 28-78, 2013.

[31] Mongolia: Financial System Stability Assessment, International Monetary Fund, Washington, D.C, May. 2011.

[32] R. M. Auty, Resource Abundance and Economic Development: Imroving the Performance of Resource-Rich Countries, Oxford University Press, 1998

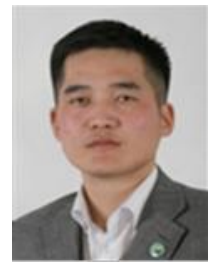

Tuvshinjargal Dagiimaa was born in 1983 in Mongolia and graduated in Mongolian State University of Education BA in economics and statistics in 2005 and he also obtained his MA in economics from National University of Mongolia in 2007.

$\mathrm{He}$ has been working at the Institute of Finance and Economics (IFE) where is one of the best higher educational organizations in economics education since 2007. From 2006 to 2008, he was one of the participants of regional seminar for excellence in teaching: Institutions and Public policy sponsored by HESP, OSI. He then has written a collaborative book of New Institutional Economics is being written by the seminar participants and published in 2009.

His major research field is macroeconomics, new institutional economics, and natural resource management. Among the several the papers he has written, the best-known include "Time inconsistency and Central bank independence in Mongolia", the proceeding of conference of IFE (2010), "Market failure and its institutional solution", the journal of Mongolian economy: Yesterday, Today, Tomorrow (2013), recently or in 2014 with Avralt-Od, P., and Batsukh, TS., "Monetary Policy Priorities: Managing Exchange rate vs. Inflation Control" in ERI Discussion Series is compiled by Economic Research Institute (ERI) is an independent policy studies center at the School of Economic Studies of National University of Mongolia with collaboration of IRIS center, University of Maryland and the paper was written in English and went through professional analysts' peer-review. 